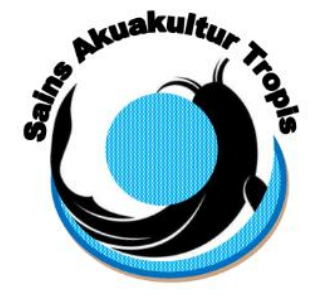

\author{
Jurnal Sains Akuakultur Tropis \\ Departemen Akuakultur \\ Fakultas Perikanan dan IImu Kelautan - Universitas Dipon o \\ JI. Prof. Soedarto, SH, Tembalang, Semarang 50275 \\ Telp. (024) 7474698, Fax.: (024) 7474698 \\ Email: sainsakuakulturtropis@gmail.com, sainsakuakulturtropis@undip.ac.id
}

\title{
PERTUMBUHAN DAN PRODUKSI TELUR HARPACTICOIDA, Tigriopus sp. DENGAN SALINITAS MEDIA YANG BERBEDA
}

Growth and Eggs Production of The Harpacticoid, Tigriopus sp. with Different Medium Salinity

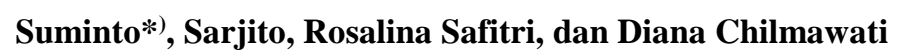

Departemen Akuakultur,

Fakultas Perikanan dan Ilmu Kelautan,

J1. Prof. Soedarto, SH, Tembalang, Semarang, Jawa Tengah -50275, Telp/Fax. +62247474698

* Corresponding author: suminto57@gmail.com

\begin{abstract}
ABSTRAK
Tigriopus sp. merupakan salah satu copepoda harpaticoida yang digunakan sebagai pakan alami zooplankton untuk pakan ikan air laut dan udang. Tigriopus sp. lebih toleran terhadap perubahan kondisi lingkungan seperti suhu dan salinitas, yang dapat berpengaruh terhadap produktivitas dan kepadatan individu. Penelitian ini bertujuan untuk mengkaji pengaruh salinitas media kultur yang berbeda terhadap pertumbuhan dan produksi telur Tigriopus sp. dan mengetahui salinitas terbaik serta salinitas optimal bagi pertumbuhan dan produksi telur Tigriopus sp. Rancangan yang digunakan ialah Rancangan Acak Lengkap (RAL) dengan 6 perlakuan dan 5 kali ulangan. Tigriopus sp. dengan kepadatan awal $1 \mathrm{ind} / \mathrm{ml}$ pada masing-masing perlakuan, dikultur pada media dengan salinitas yang berbeda selama 20 hari pemeliharaan, tanpa diberikan aerasi. Salinitas media tersebut diantaranya 14 ppt (perlakuan A), 18 ppt (perlakuan B), 22 ppt (perlakuan C), 26 ppt (perlakuan D), 30 ppt (perlakuan E) dan 34 ppt (perlakuan F). Diet mikroalga yang diberikan ialah dari jenis Chaetoceros calcitrans dan Isochrysis galbana dengan kebutuhan 511.349:231.129 sel/ind/hari. Hasil menunjukkan bahwa salinitas berpengaruh sangat nyata $(\mathrm{P}<0,01)$ terhadap pertumbuhan namun tidak berpengaruh nyata $(\mathrm{P}>0,05)$ terhadap produksi telur Tigriopus sp. Hasil terbaik ditunjukkan pada perlakuan B (salinitas media $18 \mathrm{ppt}$ ) yang menghasilkan pertumbuhan dengan jumlah individu diakhir pemeliharaan sebanyak 47,8 $\pm 0,31 \mathrm{ind} / 10 \mathrm{ml}$ dan

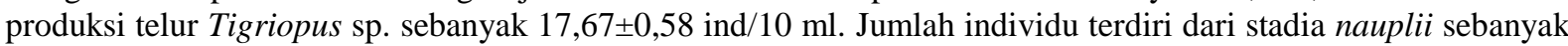
$39,4 \pm 2,3 \mathrm{ind} / 10 \mathrm{ml}$, stadia copepodit sebanyak 3,8 $\pm 1,1 \mathrm{ind} / 10 \mathrm{ml}$ dan stadia dewasa sebanyak 5,4 $\pm 2,1 \mathrm{ind} / 10 \mathrm{ml}$.
\end{abstract}

Kata Kunci : harpacticoid, Tigriopus sp., salinitas, pertumbuhan, produksi telur

\section{ABSTRACT}

Tigriopus sp. is one of copepodas harpaticoid as live food of zooplankton for fish larval rearing and shrimp. Tigriopus sp. is more tolerant to the enviromental change condition such as temperature and salinity, which can affect on the productivity and density. This study aims to examine the effect different of salinity culture media on the growth and eggs production of Tigriopus sp. and know the best salinity and optimal salinity for growth and eggs production of Tigriopus sp. This research was carried out at experimental method was used in this research, its carried out at Coastal Area Development Laboratory (CADL) Diponegoro University, Jepara. The design used was Completely Randomized Design (CRD) with 6 treatments and 5 repetitions used was Completely Randomized Design (CRD) with 6 treatments and 5 repetitions. Cultivation of Tigriopus sp. were an initial density of 1 ind/mL and cultured during 20 days culture without aeration. Those treatments were the culture media with salinity of 14 ppt (treatment A), 18 ppt (treatment B), 22 ppt (treatment C), 26 ppt (treatment D), 30 ppt (treatment E) and 34 ppt (treatment F). All the cultures were fed with a mixed algal cells of Chaetoceros calcitrans and Isochrysis galbana by ratio of 511.349: 231.129 sel/ind/day. The results showed that salinity had a significant effect $(P<0.01)$ on the growth but no significant effect $(P>0.05)$ on the eggs production of Tigriopus sp. The best result was shown in the medium salinity of 18 ppt (treatment $B$ ) which growth with a total density at the end of culture of $47.8 \pm 3.1$ 
ind/10 $\mathrm{mL}$ and the eggs production of Tigriopus sp. of $17.67 \pm 0.58 \mathrm{ind} / 10 \mathrm{ml}$ while density nauplii stage of 39.4 $\pm 2.3 \mathrm{ind} / 10 \mathrm{~mL}$, copepodite stage of $3.8 \pm 1.1 \mathrm{ind} / 10 \mathrm{~mL}$ and adult stage of $4.6 \pm 0.21 \mathrm{ind} / 10 \mathrm{~mL}$ respectively.

Keywords: harpacticoida, Tigriopus sp., salinity, growth, eggs production

Article Received: 20-12-2018; Accepted: 09-09-2019

\section{PENDAHULUAN}

Pakan alami berupa fitoplankton dan zooplankton sangat dibutuhkan sebagai asupan pakan bagi larva ikan maupun udang. Pakan yang diperlukan pada hatchery ikan maupun udang bergantung pada ketersediaan pakan alami yang disesuaikan dengan stadia kultivan. Hal ini didasarkan pada ukuran dan jenis pakan yang sesuai dengan bukaan mulut larva, sehingga larva akan dapat memanfaatkan pakan secara maksimal. Berbagai jenis pakan alami yang banyak dibudidayakan, salah satu jenis yang seringkali digunakan pada saat stadia larva ialah dari genus Copepoda.

Tigriopus sp. merupakan salah satu copepoda harpaticoid yang sifatnya epibenthic (berada diantara batas sedimen dengan air) dan telah dikembangkan dibeberapa negara seperti Korea Selatan (Lee et al., 2012), Thailand dan China (Punnarak, 2017) serta Jepang. Copepoda, harpaticoida Tigriopus sp. apabila dibandingkan dengan copepoda calanoid, lebih toleran terhadap perubahan kondisi lingkungan, mempunyai produktivitas yang tinggi dan dapat dikembangkan dalam kepadatan tinggi (Kahan et al., 1982; Cutts, 2003). Optimasi Tigriopus sp. guna meningkatkan pertumbuhan, kelangsungan hidup maupun produksi dapat dilakukan dengan mengoptimalkan kondisi media kultur, salah satunya ialah salinitas. Toleransi terhadap salinitas, umumnya berbeda-beda pada setiap spesies copepoda.

Pengembangan penelitian Tigriopus sp. terkait lingkungan (kelayakan media kultur) dalam hal ini adalah salinitas telah dilakukan oleh Punnarak et al. (2017) di Thailand. Perlakuan salinitas media berbeda yang dilakukan ialah dengan kisaran salinitas 10-40 ppt dan menghasilkan pertumbuhan paling baik pada salinitas 20 ppt. Cutts (2001), menyatakan bahwa salinitas merupakan faktor penting dalam keberhasilan budidaya copepoda. Salinitas mempengaruhi osmoregulasi pada copepoda dan penting untuk fekunditas (produksi telur) dan umur panjang dari copepoda harpacticoid, sementara kondisi ini tergantung pada spesies dan strain. Pada umumnya, harpaticoid hanya memiliki satu kantung telur dan dapat memproduksi telur sebanyak 18-29 butir/ind. Drillet et al. (2011), mengatakan bahwa copepoda secara umum hidup dilingkungan alam dengan kisaran salinitas antara 5-35 ppt, walaupun masih dalam genus yang sama, beberapa jenis copepoda memiliki rentan salinitas yang berbeda. Rentang toleransi salinitas pada Tigriopus sp. berkisar antara 15-35 ppt. Sun dan Fleeger (1995), menambahkan bahwa harpacticoida dari daerah tropis, Amphiascoides atopus mampu dikultur dengan kisaran 15,5-33,3 ppt. Beberapa penelitian yang telah dilakukan, menunjukkan bahwa copepoda harpaticoida mampu tumbuh dan berkembang biak dibawah kondisi lingkungan (salinitas) dengan kisaran salinitas tertentu.. Hal ini menjadikan penelitian terkait perbedaan salinitas media kultur terhadap performa pertumbuhan Tigriopus sp. perlu untuk diteliti.

\section{MATERI DAN METODE}

\section{a. Persiapan wadah dan kultur Tigriopus sp.}

Pakan alami dari jenis copepoda harpaticoida yang digunakan dalam penelitian adalah Tigriopus sp. Tigriopus sp. sebagai materi penelitian yang digunakan berasal dari hasil sampling di perairan pantai Bandengan, Jepara, berjarak $700 \mathrm{~m}$ dari Balai Besar Perikanan Budidaya Air (BBPBAP) yang ada di kawasan pantai Bandengan, Jepara. Hasil dari sampling, dikoleksi dalam botol kaca 1 L dengan volume air laut $500 \mathrm{ml}$ yang kemudian dipindahkan pada wadah kultur. Wadah berupa botol berbahan kaca dengan kapasitas volume $35 \mathrm{ml}$, yang diisi media air laut sebanyak $10 \mathrm{ml}$. Media air laut yang dipakai disesuaikan dengan masing-masing perlakuan, yaitu 14 ppt, 18 ppt, 22 ppt, 26 ppt, 30 ppt dan 34 ppt. Kepadatan kultur Tigriopus sp. dalam setiap botol vial yang digunakan ialah sebanyak $1 \mathrm{ind} / \mathrm{ml}$ media kultur. Pakan yang diberikan ialah dari jenis fitoplankton yaitu, Chaetoceros calcitrans berasal dari Balai Besar Perikanan Budidaya Air Payau (BBPBAP) Jepara dan Isochrysis galbana yang berasal dari Balai Besar Perikanan Budidaya Laut (BBPBL) Lampung.

\section{b. Persiapan wadah dan kultur fitoplankton}

Kultur fitoplankton meliputi kultur C. calcitrans dan I. galbana dilakukan didalam toples dengan volume 3 L. Bibit $C$. calcitrans dan I. galbana masing-masing sebanyak 0,5 L dikultur didalam toples dengan media air laut dengan salinitas $25 \mathrm{ppt}$ sebanyak $3 \mathrm{~L}$ yang telah dipupuk (Walne dan Vit. B12) sesuai dosis $0,5 \mathrm{ml} / \mathrm{l} \mathrm{media}$ kultur.

\section{c. Metode dan rancangan penelitian}

Metode yang digunakan dalam penelitian ini adalah metode eksperimen yang dilakukan dilaboratorium Pakan Hidup BBPBAP, Jepara menggunakan rancangan percobaan yaitu Rancangan Acak Lengkap (RAL) dengan 6 perlakuan dan 5 kali ulangan yang dilakukan selama 20 hari pemeliharaan, tanpa diberikan aerasi. Perlakuan mengacu pada penelitian yang dilakukan oleh Punnarak et al. (2017), yakni salinitas media kultur terbaik yang digunakan pada skala laboratorium ialah 20 ppt dengan menggunakan kisaran perlakuan 10-40 ppt. Perlakuanperlakuan tersebut adalah Perlakuan A: salinitas media kultur 14 ppt; B: salinitas media kultur 18 ppt; C: salinitas 
media kultur 22 ppt; D: salinitas media kultur 26 ppt; E: salinitas media kultur 30 ppt; dan F: salinitas media kultur 34 ppt.

Prosedur dalam penelitian ini meliputi persiapan wadah, kultur fitoplankton (C. calcitrans dan I. galbana), kultur Tigriopus sp., penebaran Tigriopus sp. pada botol vial dan pemeliharaan Tigriopus sp. selama 20 hari. Persiapan wadah meliputi sterilisasi botol vial kapasitas volume $35 \mathrm{ml}$ yang digunakan sebagai wadah kultur Tigriopus sp. dengan pencucian menggunakan deterjen, pengeringan dibawah sinar matahari dan pengovenan pada $149{ }^{\circ} \mathrm{C}$ selama 15 menit. Sterilisasi toples plastik sebagai wadah kultur fitoplankton dengan pencucian menggunakan sabun dan pengeringan dibawah sinar matahari. Kultur Tigriopus sp. dilakukan dengan melakukan koleksi terlebih dahulu dari hasil sampling Tigriopus sp. dari perairan Bandengan, Jepara. Koleksi dari hasil sampling dilakukan dengan menyaring air sampling menggunakan plankton net size 100 micron. Isolasi Tigriopus sp. dibawah miroskop dan loop dilakukan satu per satu guna mendapatkan bibit Tigriopus sp. murni. Bibit yang telah dikultur, ditebar pada masing-masing botol vial berukuran $35 \mathrm{ml}$ yang diisi air laut steril $10 \mathrm{ml}$. Kepadatan awal yang digunakan adalah $1 \mathrm{ind} / \mathrm{ml}$ Tigriopus sp. stadia dewasa yang diambil secara acak dari kultur stok dengan suhu $25^{\circ} \mathrm{C}$, pH air 8 dan tanpa diberi aerasi (Syarifah et al., 2015).

\section{d. Pengumpulan dan analisa data}

Pengumpulan data dilakukan 4 hari sekali setelah Tigriopus sp. ditebar. Data yang dapat diambil diantaranya pertumbuhan Tigriopus sp., laju pertumbuhan dan produksi telur. Pertumbuhan Tigriopus sp. meliputi dari jumlah individu total, jumlah stadia nauplii, stadia copepodit dan stadia dewasa yang dilakukan dengan menghitung individu Tigriopus sp. dari semua volume air. Laju pertumbuhan (ind/hari) dapat dihitung menggunakan rumus yang digunakan oleh Cheng et al., (2011) yaitu ln Nt - Not / T, dengan ln (Nt) adalah kepadatan puncak Tigriopus sp. In (No) adalah kepadatan awal Tigriopus sp. dan T adalah waktu puncak. Produksi telur (telur/ind) dihitung dengan membandingkan kelimpahan telur dan jumlah betina bertelur. Perhitungan telur dilakukan dengan mengambil Tigriopus sp. dewasa yang memiliki kantung telur dari setiap perlakuan dan diamati di bawah mikroskop perbesaran 10-40 kali. Rumus produksi telur menurut Zamora-Terol et al. (2014), adalah ( $\Sigma$ s x e) / $\Sigma \mathrm{n}$, dengan s adalah kantung telur, e adalah rata-rata jumlah telur setiap kantung (telur) dan $\mathrm{n}$ adalah betina bertelur (ind). Data lain yang diperoleh ialah data dari setiap stadia, diantaranya stadia nauplii, copepodit dan dewasa. Data-data tersebut dianalisa dengan analisis varian (ANOVA) menggunakan program aplikasi SPSS (25) dan Microsoft Excel (2010). Apabila hasil pengujian tersebut bersifat menyebar normal, homogen dan additif maka selanjutnya dianalisis varian (ANOVA). Apabila hasil ANOVA menunjukkan adanya perbedaaan yang nyata maka dilakukan Uji Wilayah Duncan dengan menggunakan taraf kepercayaan $95 \%$ dan $99 \%$.

\section{HASIL}

a. pertumbuhan Tigriopus sp.

Hasil yang diperoleh dari penelitian adalah performa pertumbuhan Tigriopus sp. meliputi kepadatan total (Gambar 1), kepadatan stadia nauplii (Gambar 2), copepodit (Gambar 3) dan dewasa (Gambar 4) yang tersaji pada gambar dibawah ini.

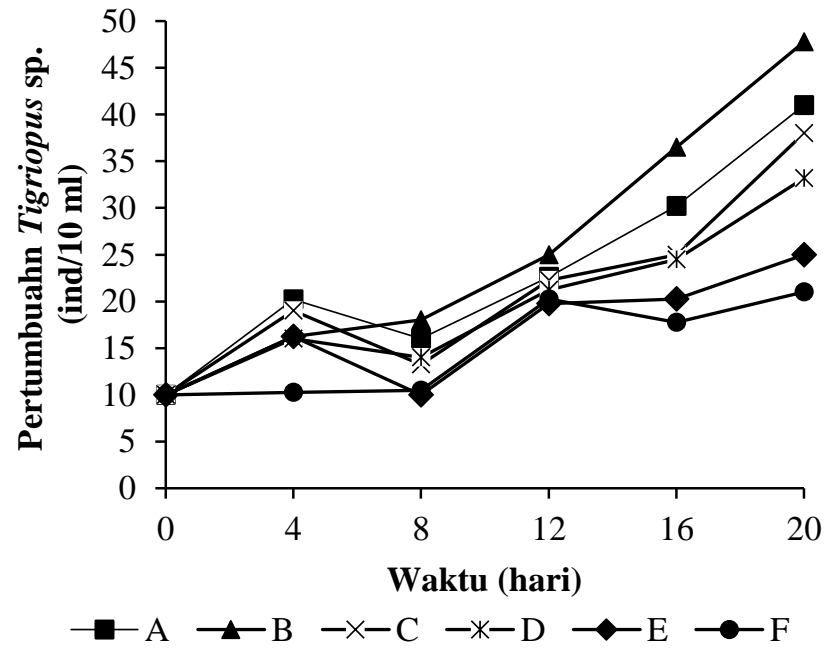

Gambar 1. Pola pertumbuhan total Tigriopus sp. selama penelitian

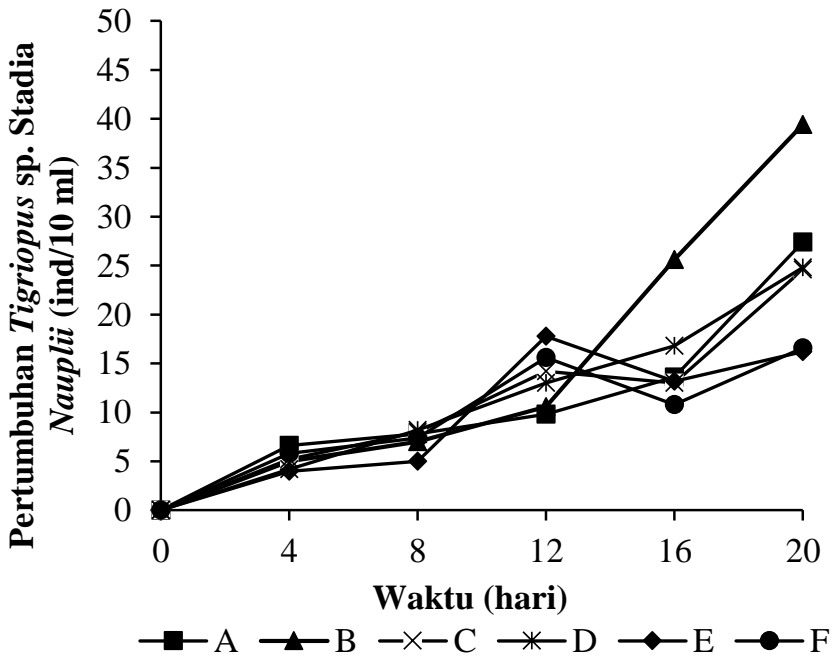

Gambar 2. Pola pertumbuhan Tigriopus sp.stadia nauplii selama penelitian 


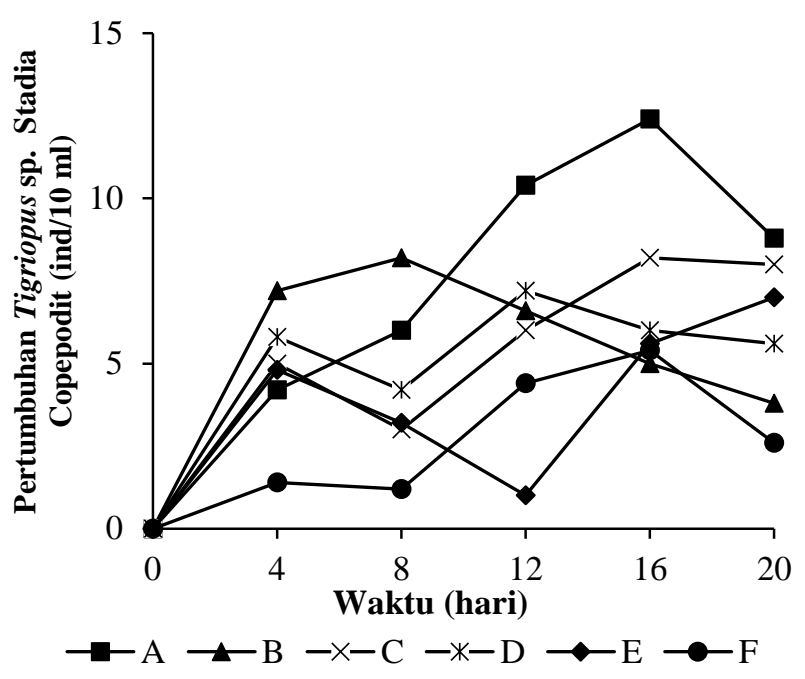

Gambar 3. Pola pertumbuhan Tigriopus sp. stadia copepodit selama penelitian

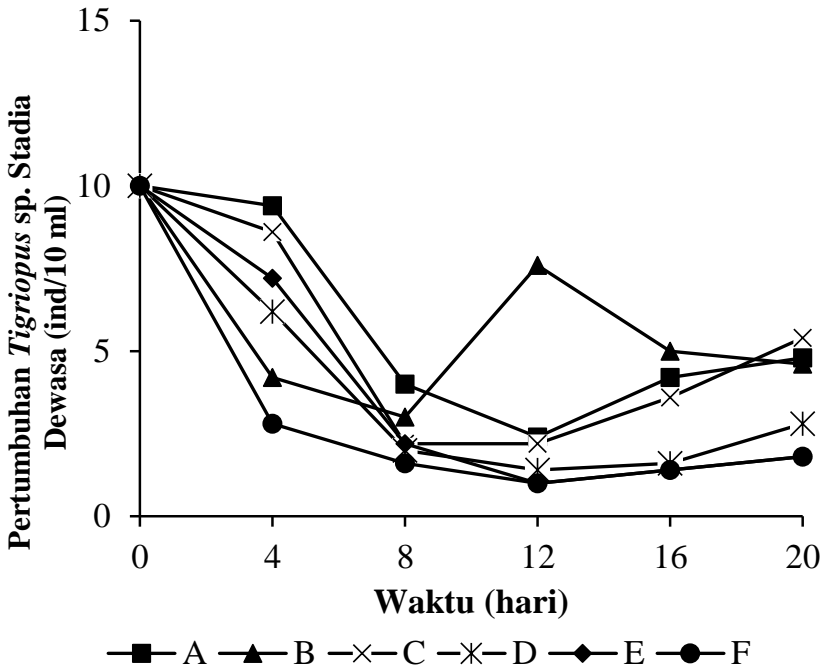

Gambar 4. Pola pertumbuhan Tigriopus sp. stadia dewasa selama penelitian

Berdasarkan hasil pemeliharaan pada Tigriopus sp. selama 20 hari, didapat data jumlah individu total, stadia nauplii, stadia copepodit dan stadia dewasa yang dapat dilihat pada tabel 1.

Tabel 1. Nilai rata-rata jumlah individu Tigriopus sp. total, stadia nauplii, stadia copepodit dan stadia dewasa dihari ke-20

\begin{tabular}{ccccc}
\hline Perlakuan & Total & Stadia Nauplii & Stadia Copepodit & Stadia Dewasa \\
\hline A & $41,00 \pm 2,55^{\mathrm{b}}$ & $27,40 \pm 2,07^{\mathrm{b}}$ & $8,80 \pm 1,48^{\mathrm{a}}$ & $4,80 \pm 2,17^{\mathrm{ab}}$ \\
B & $47,80 \pm 3,11^{\mathrm{a}}$ & $39,40 \pm 2,30^{\mathrm{a}}$ & $3,80 \pm 1,10^{\mathrm{d}}$ & $4,60 \pm 2,07^{\mathrm{ab}}$ \\
C & $38,00 \pm 3,94^{\mathrm{b}}$ & $24,60 \pm 2,41^{\mathrm{b}}$ & $8,00 \pm 0,71^{\mathrm{ab}}$ & $5,40 \pm 2,07^{\mathrm{a}}$ \\
D & $33,20 \pm 2,95^{\mathrm{c}}$ & $24,80 \pm 2,59^{\mathrm{b}}$ & $5,60 \pm 1,14^{\mathrm{c}}$ & $2,80 \pm 1,10^{\mathrm{bc}}$ \\
E & $25,00 \pm 3,39^{\mathrm{d}}$ & $16,20 \pm 2,17^{\mathrm{c}}$ & $7,00 \pm 1,22^{\mathrm{bc}}$ & $1,80 \pm 0,84^{\mathrm{c}}$ \\
F & $21,00 \pm 1,00^{\mathrm{e}}$ & $16,60 \pm 0,89^{\mathrm{c}}$ & $2,60 \pm 0,55^{\mathrm{d}}$ & $1,80 \pm 0,84^{\mathrm{c}}$ \\
\hline
\end{tabular}

Keterangan:

Nilai rerata dengan huruf superscript yang berbeda kolomyang sama menunjukkan adanya perbedaan yang nyata $(\mathrm{P}<0,05)$.

Berdasarkan rata-rata jumlah individu Tigriopus sp., total pada masing-masing perlakuan adalah perlakuan

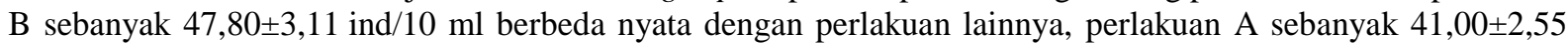
ind/10 ml tidak berbeda nyata dengan perlakuan $C$ sebanyak 38,00 $\pm 3,94 \mathrm{ind} / 10 \mathrm{ml}$. Perlakuan D sebanyak $33,20 \pm 2,95 \mathrm{ind} / 10 \mathrm{ml}$ berbeda nyata dengan perlakuan E sebanyak 25,00 $\pm 3,39 \mathrm{ind} / 10 \mathrm{ml}$ dan perlakuan $\mathrm{F}$ sebanyak $21,00 \pm 1,00 \mathrm{ind} / 10 \mathrm{ml}$. Stadia nauplii diperoleh data tertinggi dari perlakuan B sebanyak 39,40 $\pm 2,30 \mathrm{ind} / 10 \mathrm{ml}$,

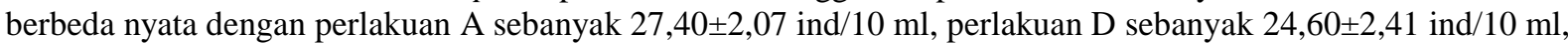

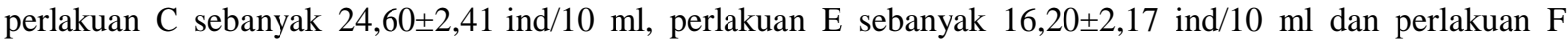
sebanyak 16,60 $\pm 0,89 \mathrm{ind} / 10 \mathrm{ml}$. Stadia copepodit diperoleh data masing-masing dari perlakuan A sebanyak $8,80 \pm 1,48 \mathrm{ind} / 10 \mathrm{ml}$, tidak berbeda nyata dengan perlakuan $\mathrm{C}$ sebanyak $8,00 \pm 0,71 \mathrm{ind} / 10 \mathrm{ml}$, namun berbeda nyata

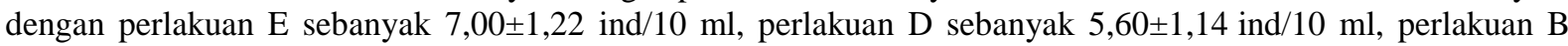

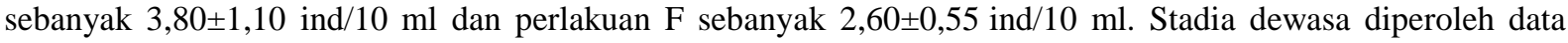
masing-masing dari perlakuan $\mathrm{C}$ sebanyak 5,40 $\pm 2,07 \mathrm{ind} / 10 \mathrm{ml}$, tidak berbeda nyata dengan perlakuan A sebanyak

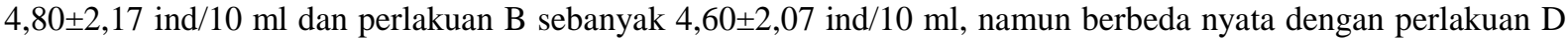

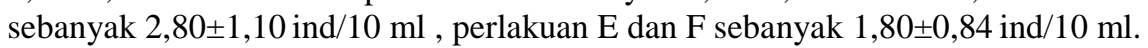


Berdasarkan hasil yang diperoleh dari pertumbuhan Tigriopus sp. dengan jumlah individu diakhir penelitian, didapatkan titik pada salinitas optimal Tigriopus sp. dapat hidup dan tumbuh dengan baik yang tersaji pada gambar 5 .

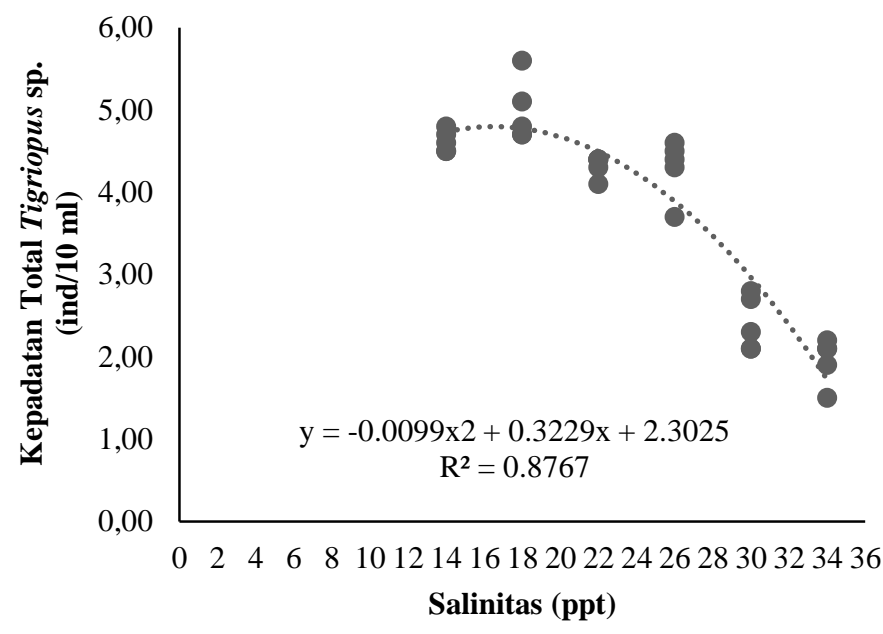

Gambar 5. Titik optimal pertumbuhanl Tigriopus sp. pada hari ke-20

Berdasarkan uji Polinomial Orthogonal diperoleh hubungan yang berpola kuadratik y $=-0.0099 \times 2+$ $0.3229 \mathrm{x}+2.3025$ dan $\mathrm{R}^{2}=0,87$ dan titik optimum diantara pada perlakuan A (salinitas $14 \mathrm{ppt}$ ) dan $\mathrm{B}$ (salinitas 18 ppt). Gambar diatas menunjukkan bahwa selama penelitian, salinitas optimal yang mendukung bagi kehidupan dan pertumbuhan dari Tigriopus sp. adalah salinitas 16,3 ppt. Koefisien determinasi dari persamaan kuartik salinitas adalah 0,87 . Hal ini menunjukkan bahwa pengaruh salinitas terhadap pertumbuhan Tigriopus sp. sebesar $87 \%$ sedangkan $13 \%$ lainnya dipengaruhi oleh faktor lain.

\section{b. laju pertumbuhan Tigriopus sp.}

Berdasarkan hasil pemeliharaan pada Tigriopus sp. selama 20 hari, didapat data laju pertumbuhan Tigriopus sp. yang tersaji pada gambar 7 .

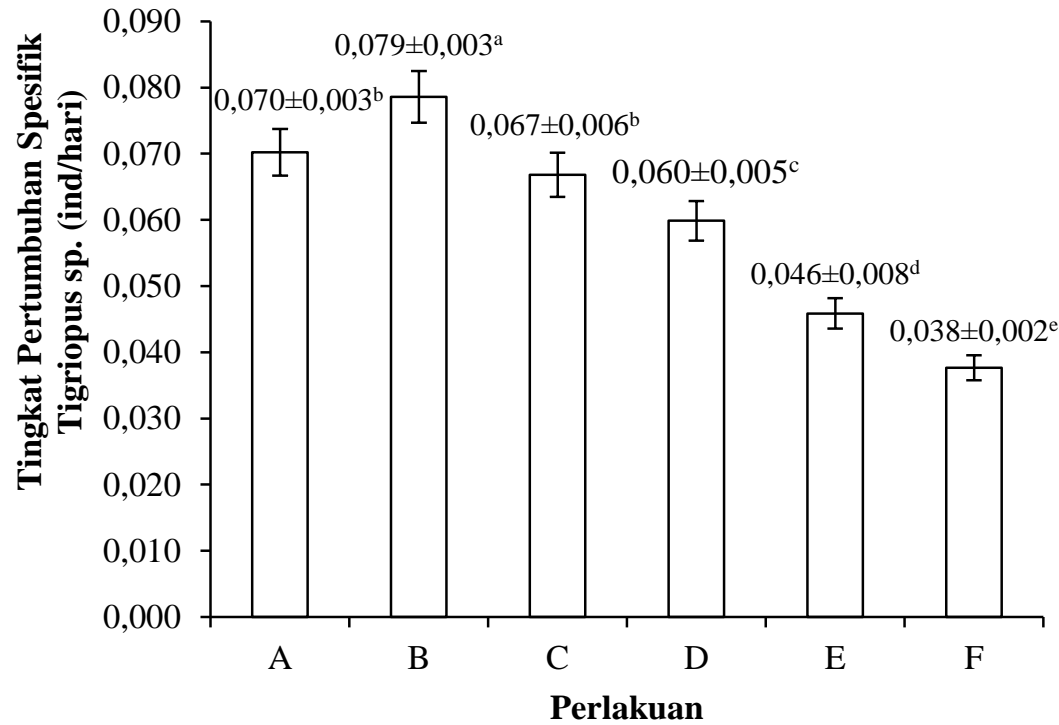

Gambar 6. Laju pertumbuhan Tigriopus sp. pada pemeliharaan hari ke-20

Berdasarkan data laju pertumbuhan Tigriopus sp., hasil tertinggi diperoleh dari perlakuan B sebesar $0,079 \pm 0,003 \mathrm{ind} / \mathrm{hari}$ berbeda nyata dengan perlakuan A sebesar 0,070 $\pm 0,003 \mathrm{ind} / \mathrm{hari}$, perlakuan $\mathrm{C} 0,067 \pm 0,006$ ind/hari, perlakuan D sebesar 0,060 $\pm 0,005$ ind/hari, perlakuan E sebesar 0,046 $\pm 0,008$ ind/hari dan perlakuan $\mathrm{F}$ sebesar $0,038 \pm 0,002$ ind/hari.

\section{c. produksi telur Tigriopus sp.}

Berdasarkan hasil pemeliharaan pada Tigriopus sp. didapat data produksi telur Tigriopus sp. pada hari ke20 yang tersaji pada gambar 8 . 


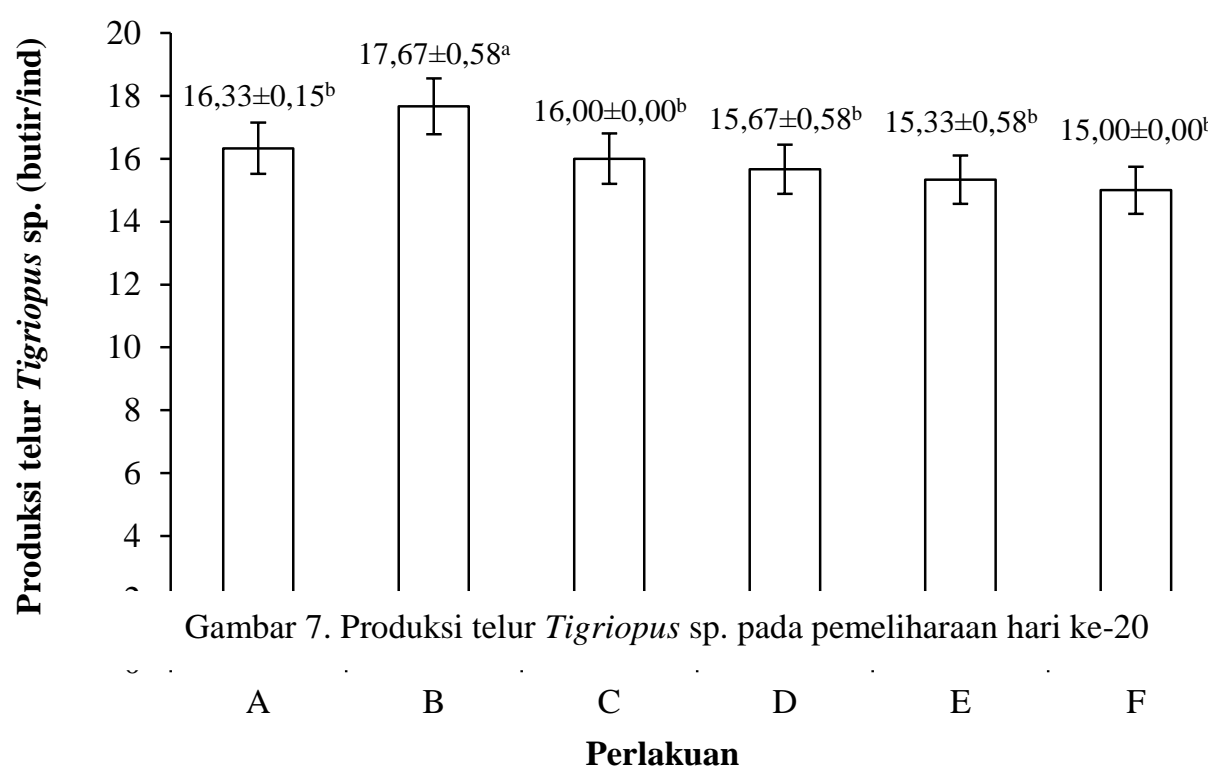

Berdasarkan data produksi telur Tigriopus sp., diperoleh hasil tertinggi ditunjukkan oleh perlakuan B sebanyak 17,67 $\pm 0,58$ butir/ind. berbeda nyata dengan perlakuan A sebanyak 16,33 $\pm 1,15$ butir/ind, perlakuan C

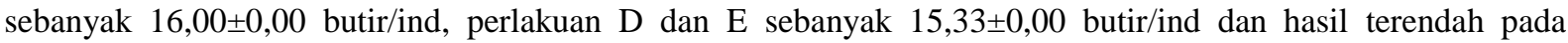

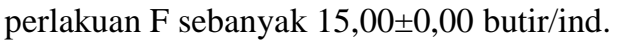

\section{PEMBAHASAN}

\section{a. pola pertumbuhan Tigriopus sp.}

Pola yang ditunjukkan oleh masing-masing stadia menunjukkan bahwa perbedaan salinitas akan mempengaruhi dalam setiap perkembangan Tigriopus sp. Stadia nauplii ditunjukkan lebih cepat mengalami pertumbuhan dan secara signifikan memiliki jumlah individu terbanyak selama 20 hari masa penelitian. Stadia copepodit lebih fluktuatif dan cenderung tidak stabil pada hari ke-4 hingga hari ke-20. Stadia dewasa cenderung lebih stabil walaupun diawal mengalami penurunan secara perlahan sedangkan untuk stadia dewasa bertelur kepadatan yang dihasilkan cenderung tidak stabil, khususnya mulai pada pengamatan dihari ke-12 hingga hari ke20. Santhanam dan Perumnal (2012), menyatakan bahwa masing-masing stadia memiliki siklus tumbuhnya masing-masing. Stadia nauplii cenderung akan membutuhkan waktu selama 4-6 hari hingga berubah menjadi stadia copepodit. Stadia copepodit membutuhkan selang waktu 4-5 hari hingga berubah menjadi stadia dewasa sedangkan dewasa hingga menghasilkan telur membutuhkan waktu kurang lebih 4-9 hari.

Berdasarkan gambar 1, terlihat pola pertumbuhan Tigriopus sp. yang hampir disetiap perlakuannya mengalami pertambahan jumlah individu secara perlahan sampai hari ke-20. Pertumbuhan Tigriopus sp. tersebut terdiri dari kepadatan nauplii, copepodit, dewasa dan dewasa bertelur. Pertumbuhan dengan jumlah individu paling banyak terlihat pada perlakuan B yaitu sebanyak 47,80 $\pm 3,11 \mathrm{ind} / 10 \mathrm{ml}$, berbeda nyata dengan perlakuan A

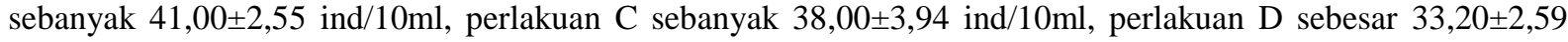

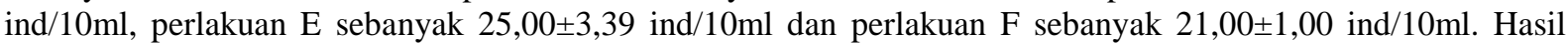
kepadatan total di atas, menggambarkan bahwa Tigriopus sp. tumbuh secara normal pada kondisi kultur tanpa aerasi, sedangkan untuk kultur Tigriopus sp. dengan menggunakan aerasi pada volume media kultur 2 L,

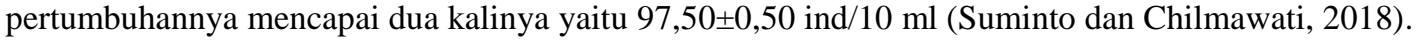

Pola pertumbuhan stadia nauplii (gambar 2) menunjukkan adanya peningkatan jumlah individu hingga dihari ke-20, kecuali pada perlakuan C, E dan F. Perlakuan tersebut mengalami penurunan jumlah individu di hari ke-16 dan naik kembali hingga hari ke-20. Puncak pertumbuhan stadia nauplii terjadi pada perlakuan B dengan jumlah individu sebanyak 39,4 $\pm 2,3$ ind/10 ml, diikuti oleh perlakuan B, D, C, F dan paling rendah pada perlakuan E sebanyak $16,2 \pm 2,2 \mathrm{ind} / 10 \mathrm{ml}$. Pola pertumbuhan stadia copepodit (gambar 3) menunjukkan pada setiap perlakuan mengalami pertumbuhan yang sangat fluktuatif. Jumlah individu paling tinggi stadia copepodit diakhir penelitian ditunjukkan oleh perlakuan A sebanyak 8,8 $\pm 1,5 \mathrm{ind} / 10 \mathrm{ml}$, diikuti oleh perlakuan C, E, D, B dan terendah pada F sebanyak 2,6 $\pm 0,55 \mathrm{ind} / 10 \mathrm{ml}$. Pertumbuhan Tigriopus sp. stadia dewasa menunjukkan pola seperti pada gambar 4. Secara bersamaan, pada masing-masing perlakuan mengalami penurunan jumlah individu hingga dihari ke-8, namun pada perlakuan D, E dan F menurun hingga di hari ke-16 dan meningkat hingga hari ke-20. Secara perlahan, perlakuan A, B dan C mengalami peningkatan jumlah individu hingga hari ke-20, namun perlakuan B menurun hingga dihari ke-16 dan ke-20. Jumlah individu stadia dewasa tertinggi terjadi pada perlakuan $\mathrm{C}$ sebesar 5,4 $\pm 2,1 \mathrm{ind} / 10 \mathrm{ml}$, dibanding dengan perlakuan $\mathrm{A}, \mathrm{B}, \mathrm{D}, \mathrm{E}$ dan perlakuan $\mathrm{F}$. 
Berdasarkan hasil analisis varian menunjukkan bahwa pengaplikasian salinitas yang berbeda pada media kultur Tigriopus sp. berpengaruh sangat nyata $(\mathrm{P}<0,01)$ terhadap pertumbuhan yang meliputi jumlah individu pada hari ke-20. Hal ini disebabkan oleh Tigriopus sp. yang mampu beradaptasi untuk bertahan hidup dan tumbuh pada kisaran salinitas 14 sampai dengan 34 ppt. Pertumbuhan pada Tigriopus sp. yang ditunjukkan diantaranya meliputi perubahan stadia yang dihasilkan selama jangka waktu pemeliharaan 20 hari. Adanya shock salinitas dari berbagai perlakuan, memberikan dampak bertahap pada Tigriopus sp. dari waktu ke waktu. Beberapa stadia dapat terlihat ada yang tidak dapat melakukan adaptasi, sehingga mengalami penurunan kepadatan. Calliari et al. (2008), menyatakan bahwa secara fisiologis, copepoda akan menunjukkan bahwa respon langsung individu terhadap salinitas tinggi umumnya melibatkan tahapan kehidupan yang dapat berubah. Kahan et al. (1988), menambahkan bahwa dalam kurum waktu kultur, respon dari $T$. japonicus yang dikultur memberikan respon terjadinya kanibalisme, predasi dari stadia dewasa pada nauplii sehingga menyebabkan berkurangnya stadia muda (copepodit) selama kultur.

Perlakuan B dalam penelitian menunjukkan pertumbuhan Tigriopus sp. dengan jumlah individu sebanyak 49,8 $\pm 0,38$ ind/10 ml merupakan hasil terbaik diantara perlakuan A, C, D, E dan F. Hal ini diduga oleh adanya kemampuan Tigriopus sp. yang dapat beradaptasi pada kisaran salinitas yang dapat mereka tolerir. Perlakuan B dengan salinitas sebesar 18 ppt diduga layak untuk menunjang bagi tumbuh dan berkembangnya Tigriopus sp. Berdasarkan stadia yang didapatkan, Tigriopus sp. mampu mencapai titik tumbuh maksimalnya pada stadia nauplii, yaitu mencapai 39,4 $\pm 2,3 \mathrm{ind} / 10 \mathrm{ml}$ pada akhir pemeliharaan. Stadia lain, seperti stadia copepodit mencapai $3,8 \pm 1,1 \mathrm{ind} / 10 \mathrm{ml}$, stadia dewasa 3,4 $\pm 0,11 \mathrm{ind} / 10 \mathrm{ml}$. Hal ini mengindikasikan bahwa pada perlakuan salinitas 18 ppt (perlakuan B), nauplii mampu bertahan hidup dan tumbuh dengan baik bila dibandingkan dengan stadia lainnya. Rhodes (2003) menyatakan bahwa kultur yang dilakukan pada copepoda jenis Nitokra lacustris, perlakuan salinitas yang berbeda menghasilkan produksi copepoda stadia nauplii yang terbaik pada salinitas 34 ppt. Peningkatan produksi nauplii lebih seringkali terjadi bila dibandingkan dengan copepodite dan dewasa. Hal tersebut dikarenakan untuk 1 ekor copepoda saja sudah menghasilkan puluhan telur yang akan menjadi nauplii dalam selang waktu antara telur hinga menetas pun relatif cepat yakni maksimal berkisar hingga 2 hari.

Salinitas 26 ppt (perlakuan C), merupakan perlakuan yang mendekati salinitas asal Tigriopus sp. yaitu kisaran 26-28 ppt. Berdasarkan data pertumbuhan, pada perlakuan $\mathrm{C}$ menunjukkan hasil yang paling banyak setelah perlakuan B dan A. Berdasarkan masing-masing pola stadia yang ada, menunjukkan adanya kecenderungan pada salinitas 26 ppt (perlakuan C) lebih layak untuk mendukung pertumbuhan Tigriopus sp. stadia dewasa dengan jumlah individu paling banyak yaitu 5,40 $\pm 2,07 \mathrm{ind} / 10 \mathrm{ml}$. Salinitas 34 (perlakuan F), merupakan perlakuan dengan salinitas paling tinggi dan menunjukkan hasil terendah dari seluruh perlakuan namun pertumbuhannys sama dengan hasil dari salinitas $30 \mathrm{ppt}$ (perlakuan E) hanya mencapai 1,80 $\pm 0,84 \mathrm{ind} / 10 \mathrm{ml}$. Tingginya salinitas pada media pemeliharaan, diduga berpengaruh pada fisiologis Tigriopus sp. Kecenderungan untuk melakukan isoosmotik dari Tigriopus sp. berdampak pada performa pertumbuhannya selama pemeliharaan. Energi yang banyak dikeluarkan untuk melakukan isoosmotik menyebabkan tahapan kehidupannya menjadi berubah sehingga kepadatan totalnya (yang meliputi tahap stadia) pun paling rendah bila dibandingkan dengan perlakuan lain. Calliari et al. (2008), mengatakan bahwa, secara fisiologis, copepoda akan menunjukkan respon langsung individu terhadap salinitas tinggi umumnya melibatkan tahapan kehidupan yang dapat berubah. Hasil yang terdapat pada gambar 1, menunjukkan bahwa pertumbuhan Tigriopus sp. pada salinitas 18 ppt (perlakuan B) merupakan perlakuan terbaik bila dibandingkan dengan perlakuan lainnya. Seiring dengan hal tersebut, dapat pula diperoleh salinitas optimum (Gambar 6). Media kultur optimum yang diperoleh ialah pada salinitas 16,3 ppt. Hal ini menunjukkan bahwa pada salinitas optimum, diharapkan dapat diterapkan untuk dilakukannya pada media kultur Tigriopus sp.

Data lain ialah nilai rata-rata laju pertumbuhan Tigriopus sp. tertinggi ditunjukkan pada perlakuan B sebesar $0,079 \pm 0,03 \mathrm{ind} / 10 \mathrm{ml}$ diikuti perlakuan A sebesar $0,070 \pm 0,03 \mathrm{ind} / 10 \mathrm{ml}$, perlakuan $\mathrm{C}$ sebesar $0,067 \pm 0,03 \mathrm{ind} / 10$

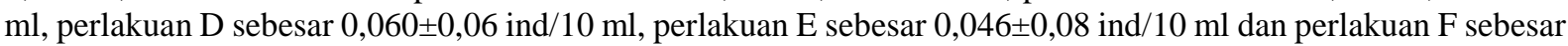
$0,038 \pm 0,00 \mathrm{ind} / 10 \mathrm{ml}$. Hasil penelitian ini menunjukkan bahwa pertumbuhan secara signifikan lebih tinggi pada tingkat salinitas $18 \mathrm{ppt}$, namun berkurang pada salinitas yang lebih rendah dan lebih tinggi. Perbedaan laju pertumbuhan yang terjadi, lebih tajam terjadi ketika salinitas paling tinggi yaitu 34 ppt. Hal ini diduga oleh tingginya salinitas pada media kultur yang tidak mampu ditolerir Tigriopus sp. sehingga mengakibatkan laju pertumbuhannya memiliki nilai paling rendah. Sejalan dengan Milione dan Zeng (2008), bahwa A. sinjiensis lebih baik mentolerir salinitas rendah walaupun pada kenyataannya mampu hidup di alam dengan salinitas hingga 40 ppt. Cutts (2001) bahwa, copepoda harpacticoida toleran terhadap variasi lingkungan, tetapi mereka memang menunjukkan respon positif ketika dibudidayakan pada keadaan lingkungan (suhu dan salinitas yang mendukung, meskipun ini tergantung pula pada spesies dan strainnya.

Faktor salinitas merupakan faktor utama terjadinya dinamika laju pertumbuhan yang terjadi pada Tigriopus sp. Beberapa jenis copepoda lain seperti Acartia sp. dan Oithona sp. secara fisiologis akan melakukan proses adaptasi yang dapat mempengaruhi laju pertumbuhan nya selama selang waktu kultur. Penelitian Punnarak et al. (2017), menyebutkan bahwa copepoda dari jenis Tigriopus sp.mampu mentolerir salinitas dengan kisaran 10-40 ppt selama selang waktu kultur dan menghasilkan laju pertumbuhan yang terbaiknya pada perlakuan dengan salinitas 20 ppt. Perbedaan nilai laju pertumbuhan untuk setiap perlakuannya dapat diindikasikan oleh adanya beberapa faktor, seperti tingkat stress dari Tigriopus sp. yang melakukan proses isoosmotiknya. Hal tersebut 
sehingga akan mempengaruhi laju pertumbuhan dari Tigriopus sp. selama selang waktu kultur. Sejalan dengan hal tersebut, Tigriopus sp. tergolong organisme air yang bersifat osmokonformer, yaitu organisme yang secara osmoregulasi labil. Hal ini dikarenakan oleh tidak adanya kemampuan pada Tigriopus sp. untuk mengatur kandungan garam serta osmolaritas dicairan internalnya. Oleh karenanya, cairan tubuhnya selalu berubah dan menyesuaikan kondisi osmolaritas media hidupnya.

\section{b. $\quad$ produksi telur Tigriopus sp.}

Pertumbuhan Tigriopus sp. dapat pula dilihat berdasarkan produksi telurnya. Produksi telur merupakan fase dimana Tigriopus sp. mampu menghasilkan telur dalam satu kantung telurnya selama jangka waku pemeliharaan. Hasil analisis varian yang telah dilakukan menunjukkan bahwa pengaplikasian salinitas yang berbeda pada media kultur Tigriopus sp.tidak berpengaruh secara signifikan $(\mathrm{P}>0,05)$ terhadap produksi telur Tigriopus sp. Perlakuan

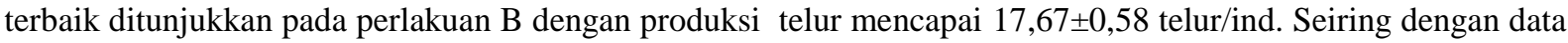
pertumbuhan, produksi telur dari Tigriopus sp. pun mengalami puncaknya pada perlakuan B. Hal ini diduga dengan adanya salinitas $18 \mathrm{ppt}$, Tigriopus sp. mampu berkembang biak untuk menghasilkan telur yang dapat menetas menjadi nauplii. Telur pada Tigriopus sp. akan lepas dari kantungnya yang kemudian menetas dengan selang waktu selama 2 hari. Powlik (1996), menyebutkan bahwa kantung telur Tigriopus sp. yang berjumlah satu tersebut mampu menghasilkan telur dengan kisaran 15-20 telur. Banyak sedikitnya produksi telur yang dihasilkan pada copepoda bergantung pada salinitas media kultur.

Sanchez et al. (2014), mengatakan bahwa salinitas berpengaruh pada pertumbuhan maupun jumlah telur yang akan dihasilkan oleh betina. Puncak produksi telur terbaik pada Acartia tonsa yang dilakukan oleh Holste dan Peck (2006) terjadi pada kultur dengan salinitas media 20 ppt dengan kisaran kultur pada salinitas 14-30 ppt. Peck et al. (2015) menambahkan bahwa salinitas 18 ppt memberikan dampak bagi produksi telur copepoda jenis Acartia sp. dengan jumlah terbanyak yaitu 37 telur sedangkan yang terendah pada salinitas 33 ppt sebanyak 26 telur.

Sejalan dengan laju pertumbuhan, banyakya produksi telur juga dipengaruhi oleh nilai salinitas media kultur. Nilai laju produksi telur terbaik diperoleh pada salinitas 18 ppt. Paparan salinitas yang semakin tinggi, menyebabkan Tigriopus sp. kurang optimal dalam menghasilkan telur disetiap kantungnya. Hal ini diperkuat oleh Damgard and Davenport (1993), Tigriopus sp. yang terpapar salinitas yang terlalu rendah ataupun terlalu tinggi dapat menyebabkan telur menjadi dorman, sehingga tidak mampu menghasilkan telur yang lebih bayak disetiap kantung telurnya.

\section{KESIMPULAN DAN SARAN \\ Kesimpulan}

Kesimpulan yang dapat diperoleh dari penelitian ini adalah perbedaan salinitas media kultur berpengaruh sangat nyata terhadap pertumbuhan Tigriopus sp. namun tidak berpengaruh nyata pada produksi telur Tigriopus sp. Nilai salinitas media kultur yang terbaik untuk memberikan pertumbuhan dan produksi telur Tigriopus sp. adalah pada salinitas 18 ppt dan nilai salinitas media kultur yang optimal untuk kultur Tigriopus sp. adalah pada salinitas 16,3 ppt.

\section{Saran}

Saran yang dapat disampaikan dari penelitian ini adalah sebaiknya pada kultur Tigriopus sp. dilakukan pada salinitas optimal, yaitu 16,3 ppt dan dilanjutkan dengan skala yang lebih besar. Pengaplikasian salinitas yang optimal pada skala yang lebih besar diharapkan mampu menghasilkan produksi yang lebih besar pula. Khususnya pada pertumbuhan stadia nauplii, yang secara umum lebih banyak dimanfaatkan sebagai pakan larva ikan maupun udang dibandingkan stadia lainnya.

\section{DAFTAR PUSTAKA}

Calliari, D., Marc C. Borg, Andersen., Thor P., Gorokhova, E., and Tiselius, P. 2008. Instantaneous Salinity Reductions Affect The Survival and Feeding Rates of The Co-occurring Copepodas Acartia tonsa Dana and A. clausi Giesbrecht Differently. Journal of Experimental Marine Biology and Ecology. 362. 18-25.

Cheng, S. H., C. S. Kuo, S. Ka, R. Kumar and J. S. Hwang. 2011. Effect of Salinity, Food Level, and The Presence of Microcrustacean Zooplankters on The Population Dynamics of Rotifer Branchionus rotundiformis. Hydrobiologia., 666: 289-299.

Cutts, C.J., 2001. Culture of Harpacticoid Copepodas: Potential as Live Feed for Rearing Marine Fish. Adv. Mar. Biol. 44, 295-316.

Damgard, R. M. and J. Davenport. 1993. Salinity Tolerance, Salinity Preference and Temperature Tolerace in The High-Shore Harpaticoid Copepoda Tigriopus brevicornis. Marine Biology. 443-449.

Drillet G., Frouel S., Sichlau M.H., Jepsen P.M., Hojgaard J.K., Joarder A.K. and Hansen B.W. 2011. Status and Recommendations on Marine Copepoda Cultivation for Use as Live Feed. Aquaculture 315, 155 -166. 
Holste, L., and Peck, M.A. 2006. The Effects of Temperature and Salinity on Egg Production and Hatching Success of Baltic Acartia tonsa (Copepoda:Calanoida): a Laboratory Investigation. Marine Biology 148, 1061-1070.

Kahan, D., G., Uhlig, D. Schwenzer and L. Horowitz. 1982. A Simple Method for Cultivating Harpacticoid Copepodas and Offering Them to Fish Larva. Aquaculture. 26 : 303-310.

Kahan, D., Y. Berman and T. Bar-el. 1988. Maternal Inhibition of Hatching at High Population Density in Tigriopus japonicus (Copepoda, Crustacea).Bio. Bull. 17. 174: 139-144.

Lee, K. W., Dahms, H. U., Park, H. G and Jung H. K. 2012. Population Growth and Productivity of The Cyclopoid Copepodas Paracyclopina nana, Apocyclops royi and The Harpacticoid Copepoda Tigriopus japonicus in Mono and Polyculture Conditions: a Laboratory Study. Aquaculture Reasearch. 1-5.Milione, M. and C. Zeng, 2008. The Effects of Temperature and Salinity on Population Growth And Egg Hatching Success oThe Tropical Calanoid copepoda, Acartia sinjiensis. Aquaculture, 275: 116-123.

Nugraha, M. F. I. dan Intanurfemi, B. H. 2011. Copepoda : Sumbu Kelagsungan Biota Akuatik dan Kontribusinya Untuk Akuakultur6 (1) :13-20.

Peck, N. Peter S. J. Rabea Diekmann. Laakmann, S., and Jasmin Renz. 2015. Interactive Effects Of Temperature And Salinity On Population Dynamics Of The Calanoid Copepoda Acartia Tonsa. Journal Plankton Resourch. 37(1): 197-210.

Powlik, J. J. 1996. Ecology of Trigiopus californicus (Copepoda, Harpaticoida) in Barkley Sound, British Columbia. Thesis. The Uni versity of Columbia. 324-343

Punnarak, P., P. Jarayabhand and A. Piumsomboonac. 2017. Cultivation of Harpacticoid Copepodas (families harpacticidae and laophontidae) under selected environmental conditions. Agriculture and Natural Resources. 51 (4) :278-285

Rhodes, A.C.E., 2003. Marine harpacticoid Copepoda Culture for the Production of Long Chain Highly Unsaturated Fatty Acids and Carotenoid Pigments. Graduate Faculty of North Carolina State University, Raleigh, NC, USA (Ph.D. thesis). 161 p.

Rippingale, R. J. and M. F. Payne. 1996. Intensive Cultivation of a Calanoid Copepoda for Live Food in Fish Culture. Project No. 1996/398. Curtin University of Technology. Perth-Australia. 62 p.

SĀnchez, A., M. A. Anzueto, B. Baraen-Sevilla, B. C. Esquivel and A. C. Ortega. 2014. Effects of Food Concentration and Temperature on Development, Growth, Reproduction and Survival of The Copepoda Pseudodiaptomus euryhalinus. Aquaculture Int. 22: 1911-1923.

Santhanam, P. and P. Perumal. Evaluation of The Marine Copoepod Oithona sp.rigida Giesbre As Lived Feed for Larviulture of Asian Seabass Lates calalifer Bloh with Special Reference to Nutritional Vaue. Indian J. Fish. 59 (2): 127-134.

Syarifah, D. H. Suminto dan D. Chilmawati. 2015. Produksi Nauplii dan Copepodit Oithona sp. Yang Dikultur dengan Perbedaan Diet Mikroalga (Chlorella vulgaris, Chaetoceros calcitrans, dan Isochrysis galbana). Journal of Aquaculture Management and Technology. 4 (3) : 69-74.

Stottrup, J.G. 2006. A Review On The Status And Progress In Rearing Copepodas For Marine Larviculture. Advantages and Disadvantages Among Calanoid, Harpacticoid and Cyclopoid Copepodas. Avences En Nutrición Acuícola VIII. Memorías Del Octavo Simposium Internacional Denutrición Acuícola, Mazatlán, Sinaloa, Mexico. 62-83.

Sun, B. \& Fleeger, J.W. (1995). Sustained mass culture of Amphiascoides atopus, a marine harpacticoid copepoda in a recirculating system. Aquaculture 136:313-321.

Uhlig, G. 1984. Progress in Mass Cultivation of Harpacticoid Copepodas for Mariculture Purposes. Spec. Publ. Eur. Maricult. Soc. 8 : 261-273.

Zamora-Terol, S., R. Swalethorp., S. Kjellerup., E. Saiz. T.G. Nielsen. 2014. Population Dynamics and Production Of The Small Copepoda Oithona sp. in a Subarctic Fjord of West Greenland. Polar Biol. 37: 953 - 965. 